\title{
Gramsci: os intelectuais e a produção da teoria
}

Regilson Maciel Borges

Mestrando em Educação pela PUC-Campinas

\section{Resumo}

O presente texto resulta de trabalho apresentado como pôster no Seminário de Estudos “Os Intelectuais e a Educação", realizado de 19 a 23 de outubro na Faculdade de Educação da Unicamp, sob o tema "Gramsci e a Educação". A intenção é apresentar resultado de leitura e fichamento realizada a partir dos Cadernos do Cárcere no item que trata acerca dos Intelectuais. Temas como o Estado Educador, os Intelectuais, Filosofia da Práxis, correspondem à fundamentação teórica da pesquisa que estamos desenvolvendo sobre Avaliação Educacional em Revista. Daí a relevância de Gramsci para nossa investigação.

Palavras-Chave: Gramsci; Intelectuais; Teoria em Avaliação.

\section{Resumen}

Este texto proviene de un documento presentado como póster en el seminario de estudio "Los intelectuales y la educación", celebrada del 19 al 23 de octubre en la Facultad de Educación de la Unicamp, bajo el lema "Gramsci y la educación". La intención es presentar los resultados de la lectura y la categorización realizadas desde la Cuadernos de la cárcel en la sección acerca de los intelectuales. Cuestiones tales como el Estado educador, los intelectuales, filosofía de la praxis, corresponden a la fundamentación teórica de la investigación que se están desarrollando de Evaluación Educativa en el Diario. De ahí la importancia de Gramsci para nuestra investigación.

Palabras clave: Gramsci; Los Intelectuales; La Teoría en la Evaluación. 
$\mathrm{O}$ trabalho objetiva apresentar a divisão feita por Gramsci entre o intelectual produtor e o reprodutor de Teoria, definidos respectivamente como "intelectuais de alto grau" e "modestos 'administradores' e divulgadores da riqueza intelectual já existente, tradicional, acumulada" (GRASMCI, 2004, v. 2, p.21).

O pensamento de Gramsci encontra-se inserido como matriz teórica da pesquisa que estamos realizando no Programa de Pós-Graduação em Educação da PUC-Campinas intitulada "Concepções de Avaliação Educacional em Questão”, onde nos propomos analisar a produção sobre avaliação educacional publicada pela Revista Ensaio: Avaliação e Políticas Públicas em Educação no período de 1993 a 2008.

Ao olharmos para os artigos que estão publicados num veículo de comunicação reconhecido pela comunidade científica (Qualis A2/CAPES), procuraremos discutir o papel do pesquisador enquanto agente "produtor" de teorias, haja vista ser tarefa dos "intelectuais de alto grau" produzir conhecimento, criar teorias. Acreditamos que o intelectual é aquele que não somente faz novas descobertas, mas também tenta difundi-las, analisando-as criticamente. Nesse sentido destaca-se a importância de um periódico científico que ajude com a divulgação de pesquisas, levantamentos, estudos, discussões e outros trabalhos críticos no campo da educação.

Na visão de Gramsci a atitude crítica e a busca de soluções viáveis frente aos problemas são inerentes à atividade intelectual. De modo que o verdadeiro intelectual não é mais concebido como um pesquisador desinteressado, mas encontra-se inserido numa realidade "como construtor, organizador, persuasor permanente" (GRAMSCI, 2004, v.2, p.53). A conclusão de Gramsci é que, a sua maneira, todos os homens são intelectuais, ainda que nem todos desempenham na sociedade a função de intelectuais; ainda, segundo Gramsci estes podem ser: cosmopolitas, tradicionais ou orgânicos. É o intelectual orgânico que, por meio da filosofia da práxis, ajudará as massas a atingir um patamar superior. 


\section{Referências bibliográficas}

GRAMSCI, A. Cadernos do Cárcere, volume 2. Trad. Carlos Nelson Coutinho. Rio de Janeiro: Civilização Brasileira, 2004. 